\title{
Process simulation of biodiesel production from vegetable oil deodorization distillate using hydrotalcite-hydroxyapatite as catalyst
}

\author{
Simulação do processo de produção de biodiesel a partir do destilado de desodorização de óleos \\ vegetais usando hidrotalcita-hidroxiapatita como catalisador
}

Simulación de proceso de producción de biodiesel a partir de destilado de desodorización de aceites vegetales utilizando hidrotalcita-hidroxiapatita como catalizador

Received: 04/25/2021 | Reviewed: 05/05/2021 | Accept: 05/08/2021 | Published: 05/26/2021

\author{
Laura A. de Almeida \\ ORCID: https://orcid.org/0000-0002-8804-6032 \\ Universidade Federal Rural do Rio de Janeiro, Brazil \\ E-mail: elaura1926@ hotmail.com \\ Renata N. Vilas Bôas \\ ORCID: https://orcid.org/0000-0002-0061-8703 \\ Universidade Federal Rural do Rio de Janeiro, Brazil \\ E-mail: revilasboas@ufrrj.br \\ Marisa F. Mendes \\ ORCID: https://orcid.org/0000-0001-8595-3019 \\ Universidade Federal Rural do Rio de Janeiro, Brazil \\ E-mail: marisamf@ufrrj.br
}

\begin{abstract}
In There are few simulation studies in the literature focusing on the production of biodiesel from vegetable oil deodorization distillate (VODD), a waste originating from the vegetable oil processing stage, using hydrotalcitehydroxyapatite as a heterogeneous catalyst. In this study, the simulation process was performed using open interface software DWSIM ${ }^{\circledR}$ Version 6.3. The motivation relied on the positive performance of the catalyst during the experimental studies. So, in the simulator design, the lipid raw material, ethanol, and the catalyst were fed together in a CSTR-01 conversion reactor. The thermodynamic fluid package used for this process was the Non-Random TwoLiquid (NRTL) activity coefficient model. The process flowchart consisted of the reaction step (oil transesterification), and separation steps of the ethyl esters produced, excess ethanol and purification of biodiesel. As a result, different scenarios were simulated, using commercial soybean oil as a comparative form, different types of catalysts and different molar ratios of alcohol and VODD. Among the main differences between the simulated cases, it was demonstrated that the excess of alcohol (1:45) caused greater quantity of VODD consumption, and consequently the greater formation of ethyl esters (biodiesel), resulting higher conversions (> 95\%). In addition, the results obtained confirmed the adequacy of VODD as a potential raw material to produce biodiesel, as it is relatively cheaper than edible oils and contributes to the use of waste. Thus, confirming that the chemical catalyst was able to form the main esters of fatty acids even using a residual raw material.
\end{abstract}

Keywords: Biodiesel; DWSIM; Heterogeneous catalysis; Simulation; Transesterification.

\section{Resumo}

Existem poucos estudos de simulação na literatura com foco na produção de biodiesel a partir do destilado da desodorização de óleo vegetal (DDOV), um resíduo originado da etapa de processamento do óleo vegetal, utilizando hidrotalcita-hidroxiapatita como catalisador heterogêneo. Neste estudo, o processo de simulação foi realizado no software de interface aberta DWSIM ${ }^{\circledR}$ Versão 6.3. A motivação baseou-se no desempenho positivo do catalisador durante os estudos experimentais. Assim, no projeto do simulador, a matéria-prima lipídica, o etanol e o catalisador foram alimentados juntos em um reator de conversão CSTR-01. O pacote de fluido termodinâmico usado para este processo foi o modelo de coeficiente de atividade de dois líquidos não aleatórios (NRTL). O fluxograma do processo consistiu na etapa de reação (transesterificação do óleo), e etapas de separação dos ésteres etílicos produzidos, excesso de etanol e purificação do biodiesel. Como resultado, diferentes cenários foram simulados, usando óleo de soja comercial como forma comparativa, diferentes tipos de catalisadores e diferentes razões molares de álcool e DDOV. Dentre as principais diferenças entre os casos simulados, foi demonstrado que o excesso de álcool (1:45) ocasionou maior quantidade de consumo de DDOV e, consequentemente, maior formação de ésteres etílicos (biodiesel), resultando em maiores conversões (> 95\%). Além disso, os resultados obtidos confirmaram a adequação do DDOV como matéria-prima com potencial para a produção de biodiesel, por ser relativamente mais barato que os óleos 
comestíveis e contribuir para o aproveitamento de resíduos. Assim, comprovando que o catalisador químico foi capaz de formar os principais ésteres dos ácidos graxos mesmo utilizando uma matéria-prima residual.

Palavras-chave: Biodiesel; DWSIM; Catálise heterogênea; Simulação; Transesterificação.

\section{Resumen}

Existen pocos estudios de simulación en la literatura con enfoque en la producción de biodiesel a partir del destilado de desodorización de aceite vegetal (DDOV), un residuo proveniente de la etapa de procesamiento del aceite vegetal, utilizando hidrotalcita-hidroxiapatita como catalizador heterogéneo. En este estudio, el proceso de simulación se realizó utilizando el software de interfaz abierta DWSIM® Versión 6.3. La motivación se basó en el desempeño positivo del catalizador durante los estudios experimentales. Así, en el proyecto del simulador, la materia prima lipídica, el etanol y el catalizador se alimentaron juntos en un reactor de conversión CSTR-01. El paquete de fluido termodinámico utilizado para este proceso fue el modelo de coeficiente de actividad de dos líquidos no aleatorios (NRTL). El diagrama de flujo del proceso consistió en la etapa de reacción (transesterificación de aceite) y etapas de separación de los ésteres etílicos producidos, etanol en exceso y purificación del biodiesel. Como resultado, se simularon diferentes escenarios, utilizando aceite de soja comercial como forma comparativa, diferentes tipos de catalizadores y diferentes relaciones molares de alcohol y DDOV. Entre las principales diferencias entre los casos simulados, se demostró que el exceso de alcohol (1:45) provocó una mayor cantidad de consumo de DDOV y, en consecuencia, una mayor formación de ésteres etílicos (biodiesel), resultando en mayores conversiones (>95\%). Además, los resultados obtenidos confirmaron la idoneidad del DDOV como materia prima con potencial para la producción de biodiésel, ya que es relativamente más económico que los aceites comestibles y contribuye al aprovechamiento de residuos. De esta forma, se demostró que el catalizador químico era capaz de formar los principales ésteres de ácidos grasos incluso utilizando una materia prima residual.

Palabras clave: Biodiesel; DWSIM; Catálisis heterogénea; Simulación; Transesterificación.

\section{Introduction}

By-products originating from the vegetable oil processing stage, such as vegetable oil deodorization distillate (VODD) has been recognized as a potential raw material for producing biodiesel, as it is relatively cheaper than edible oils (Aboelazayem; Gadalla; Saha, 2018; Zhang et al., 2003). VODD is an important by-product in the process of refining vegetable oils, such as soybean oil, corn and canola, and the amount of VODD is about $0.3-0.5 \%$ of the raw material. Normally, it contains tocopherols (3-12\%), triglycerides (45-55\%), free fatty acids (FFA, 25-35\%), sterols (7-8\%), hydrocarbons, and other unsaponifiable in small quantities. Free fatty acid (FFA) and triglycerides, present up to $80 \%$ of VODD can be transformed into biodiesel (Vilas Bôas et al., 2020; Yin et al., 2016; Wang et al., 2006).

According to ANP (National Agency of Petroleum, Natural Gas and Biofuels), biodiesel is mainly produced by transesterification and esterification of vegetable oils and animal fats, using homogeneous or heterogeneous catalysts, composed of monoalkyl esters of long-chain fatty acids (alkyl esters of fatty acids, FAAE) (Guldhe et al., 2015; Borugadda \& Goud, 2012; Yusuf; Kamarudin; Yaakub, 2011; ASTM D6751-15; Ma \& Hanna, 1999). Several factors, such as raw material, concentration and type of catalyst, free fatty acid content, temperature, reaction time, and molar ratio alcohol/oil influence the ideal biodiesel yield (Wong et al., 2019; Aghbashlo et al., 2018). Other factors, such as sustainability of various raw materials, catalytic methods, optimization of process parameters, and improvement of product quality, have been investigated by researchers to make the process of producing biodiesel by transesterification economically viable and ecologically correct (Hanif et al., 2018).

Moreover, edible oils are considered the main raw materials to produce biodiesel, and most of the existing biodiesel production plants depend on the use of edible vegetable oils derived from soy, canola, palm, and coconut (Okullo \& Tibasiima, 2017; Knothe, 2001). However, due to the continuous discussion involving the food industry, the high cost of the edible oils and their impact on the economic analysis of biodiesel process, alternative raw materials have been studied in order to investigate new and low-cost processes. Morever, the second-generation raw material is considerably cheaper than edible oil, which contributes to reduce the overall cost of biodiesel produced (Micic et al., 2016). 
Another characteristic that directly impacts the biodiesel production is the separation of the homogeneous catalysts, hindering its separation and reusing after the reaction (Lee \& Wilson, 2015). Because of this, heterogeneous catalysts are receiving considerable attention due to their characteristics as recyclable, non-corrosive, and easily separation and purification steps (Yin et al., 2016). Currently, several basic solid catalysts have been reported, mainly alkaline earth, transition metal oxide, clays (such as bentonite and hydrotalcite), anion exchange resins, etc. (Chen et al., 2015). However, few of these catalysts due to that, this study has as goal the simulation of biodiesel on a commercial scale due to the cost of synthesis of the catalyst.

Recently, the synthesis of a material composed of the hydrotalcite and hydroxyapatite phases [HT-HAp: $\left.\left(\mathrm{Mg}_{6} \mathrm{Al}_{2}(\mathrm{OH})_{16} \mathrm{CO}_{3} .4 \mathrm{H}_{2} \mathrm{O}\right)\left(\mathrm{Ca}_{10}\left(\mathrm{PO}_{4}\right)_{6}(\mathrm{OH})_{2}\right)\right]$ has been proposed, and its performance evaluated in the transesterification of soybean and water treatment (Rodrigues et al., 2018). Several studies have investigated the conditions of synthesis and composition of hydrotalcite and hydroxyapatites in the catalytic performance in biodiesel production (Vilas Bôas et al., 2020; Coral et al., 2019; Navajas et al., 2018; Brasil et al., 2017; Essamlali et al., 2017).

On the other hand, simulation data concerning the simulation of the biodiesel production using these types of catalysts are scarce in the literature. These simulations can provide information that is difficult to access through experiments, such as transient flow behavior and velocity, pressure, and concentration fields. Since validated, a numerical model also allows the prediction of the process performance under different conditions, reagents, and reactor configuration (Sousa; Santana; Taranto, 2020; Yang et al., 2017).

Abdurakhman, Putra and Bilad (2017) simulated the technical-economic feasibility and the process of biodiesel synthesis from residual cooking oil using a heterogeneous catalyst in a membrane reactor. More recently, Giwa and Umanah (2019) estimated the optimal parameters of the biodiesel process from residual cooking oil and methanol in the presence of an alkaline catalyst using a model equation developed for the system. After having the estimated optimal parameters, they were validated with the Aspen HYSYS model of the process, in which the simulation of the Aspen HYSYS model developed to produce biodiesel obtained estimated errors of less than $5 \%$.

Moreover, there are few studies on the simulation of biodiesel synthesis using VODD as a residual raw material, mainly using hydrotalcite-hydroxyapatite as a heterogeneous catalyst. However, efforts were made in this study to provide detailed information on this process through numerical simulations using open interface software, DWSIM ${ }^{\circledR}$ Version 6.3. Morais et al. (2010) used the Aspen PLUS process simulator to compare process alternatives for the production of biodiesel from residual vegetable oils.

Due to that, this study has as goal the simulation of biodiesel production from VODD in the presence of the hydrotalcite-hydroxyapatite catalyst using the DWSIM ${ }^{\circledR}$ V6.3 software. The experimental conditions applied in the simulations were obtained and were well discussed in Vilas Bôas et al. (2020). In addition, this study may increase the novelty of the combination of hydrotalcite and hydroxyapatite materials as catalysts, especially in the transesterification of residual raw materials in biodiesel.

\section{Methodology}

The data from the experiments were described by Vilas Bôas et al. (2020). The syntheses of the hydrotalcite -HT, and hydroxyapatite -HAp materials were performed using the co-precipitation method at constant $\mathrm{pH}$, in which occurred a mixture of the HT and HAp materials synthesized to form the HT-HAp material. After obtaining the materials, they were characterized by X-ray diffraction (XRD), $\mathrm{N}_{2}$ adsorption and desorption, infrared spectral analysis (FT-IR), thermogravimetric analysis (TG), and morphology. The characterization of the materials (HT, HAp, HT-HAp) confirmed that all materials presented the typical peaks of HT and HAp and in the HT-HAp material there was a better crystalline ordering. It was also observed that the 
materials showed mesoporosity in relation to the pore diameters. The HT-HAp material, after characterization, was calcined in a muffle at $700{ }^{\circ} \mathrm{C}$ at a heating rate of $5{ }^{\circ} \mathrm{C} \cdot \mathrm{h}^{-1}$ and later used as a catalyst in the production of biodiesel from the residual raw material VODD and ethanol. The transesterification reactions were carried out at a reaction temperature of $70{ }^{\circ} \mathrm{C}$, a $45: 1 \mathrm{molar}$ ratio of ethanol/VODD, and a concentration of 5\% (wt.) of HT-HAp catalyst. In which, conversion to considerable ethyl esters was obtained (about $91.5 \pm 4.5 \%$, in just $6 \mathrm{~h}$ of reaction), thus confirming that the chemical catalyst was able to form the main esters of fatty acids even using by-products as raw material (Vilas Bôas et al., 2020).

The data taken from the experimental section were used in simulations of the biodiesel production process using the DWSIM $^{\circledR}$ Version 6.3 software, estimating the parameters and the optimal process conditions.

\subsection{Process simulation using DWSIM ${ }^{\circledR}$ Version 6.3}

The DWSIM ${ }^{\circledR}$ Version 6.3, CAPE-OPEN, open-source and free chemical process simulator (Medeiros, 2021), was used to simulate the biodiesel production process using the experimental data present and already published in Vilas Bôas et al. (2020).

The process flowsheet is shown in Figure 1. The thermodynamic model chosen to represent the liquid phase was the two-liquid non-random activity coefficient (NRTL) model. The packet choice was due to the polar nature of most components of the process (Hussein et al., 2021; Zhang et al., 2003b). The chemical components of the system were triglycerides, ethanol, hydrotalcite-hydroxyapatite, sodium hydroxide, glycerol, ethyl esters, and water. The DWSIM ${ }^{\circledR}$ component library did not contain information of hydrotalcite-hydroxyapatite, triglycerides, ethyl esters, and triglycerides. Therefore, the components that were not present in the program database were registered according to the UNIFAC methodology. The VODD was represented by its main fatty acids, as linoleic acid (62\%) and oleic acid (38\%). The biodiesel, represented by the ethyl esters, were chosen from the DWSIM ${ }^{\circledR}$ component library as ethyl linoleate and ethyl oleate.

The main operational units in the process included conversion reactors, extraction columns, and separators according to the flowchart of the simulation processes shown in Figure 1. In addition, there were auxiliary equipments such as heat exchangers, pumps, coolers, heaters, and mixers. According to Figure 1, fresh ethanol was mixed with the catalyst (5\% wt.) in MIX-01, and then the mixture flow enters the CSTR-01 biodiesel reactor together with the pre-heated oil. Different molar ratios of ethanol to the oil of 6:1,12:1, and 45:1 and different types of catalysts were used, such as hydrotalcite-hydroxyapatite and sodium hydroxide ( $5 \%$ wt.). The use of sodium hydroxide was chosen because it is the traditional catalyst used, and it is important to compare the results. The reaction operational conditions were $70^{\circ} \mathrm{C}$ and $101 \mathrm{kPa}$.

The process flowchart consisted of the reaction step (oil transesterification) and separation of the ethyl esters produced, excess ethanol and purification of biodiesel. A liquid-liquid extraction column was used to simulate the separation and purification of ethyl esters, and heated water was used as solvent. Subsequently, the biodiesel was sent to a flash tank under vacuum for the evaporation of water and residual ethanol. The extraction step was represented by an absorption column in DWSIM ${ }^{\circledR}$ simulator. The variables that have been defined were the streams, top and bottom pressure, and the number of stages of the column. The biodiesel product was removed from the bottom in the CS-02 stream. The reaction conditions were taken as the optimum conditions reached from the experiments already published in Vilas Bôas et al. (2020). The comparison between experimental and numerical results was qualitative. The effect of variations in the process variables was evaluated for the conversion of the reaction. In which the standard deviation of the conversion to ethyl esters, experimental and numerical was compared. 
Figure 1. Process flow diagram of the biodiesel production processes with: (a) VODD as a lipid raw material and HT-HAp as a catalyst; (b) VODD as a lipid raw material and $\mathrm{NaOH}$ as a catalyst; (c) commercial soy oil as a lipid raw material and HTHAp as a catalyst.

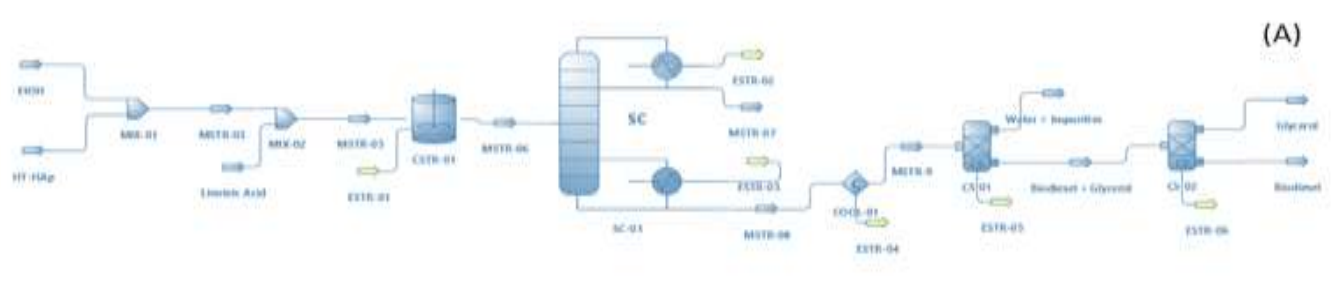

(B)
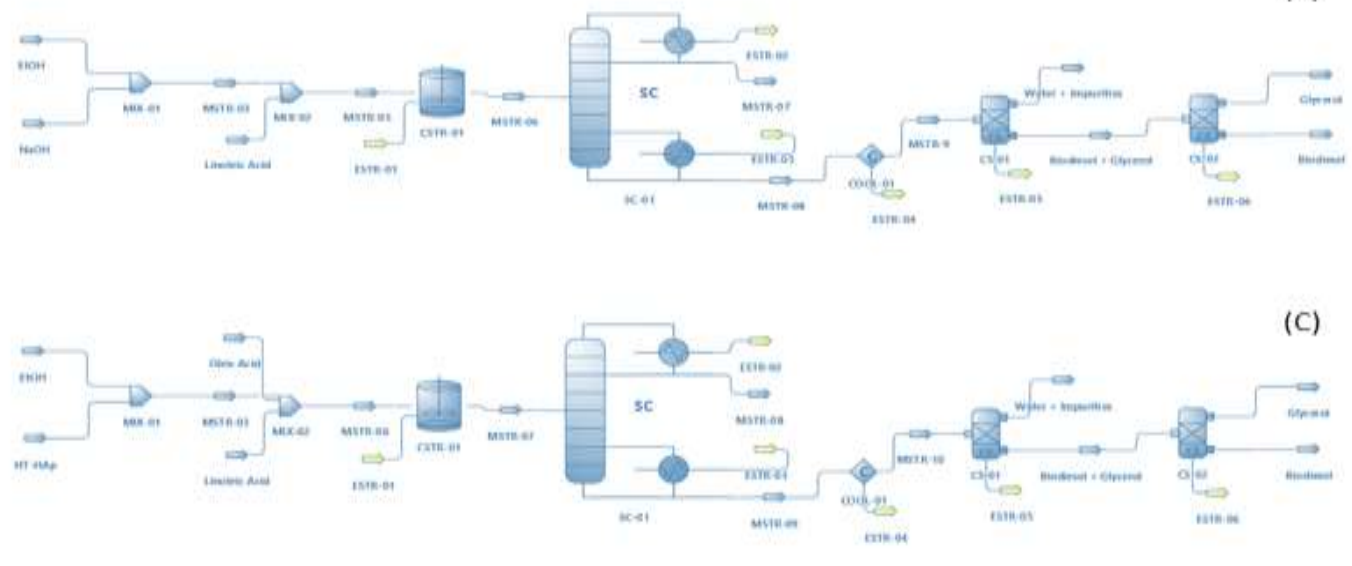

Source: Authors.

\section{Results and Discussion}

Different scenarios were simulated for the production of biodiesel on an industrial scale, varying the type of raw material, catalyst and molar ration. The first strategy used VODD and commercial soybean oil as lipid raw materials. Meanwhile, the second strategy investigated the use of different types of catalysts, such as hydrotalcite-hydroxyapatite (HTHAp) being a heterogeneous catalyst and sodium hydroxide $(\mathrm{NaOH})$ as the homogeneous catalyst. There was also a third strategy, which investigated the use of different molar ratios of 1:6, 1:12, and 1:45 of oil/alcohol. Subsequently, each strategy was analysed about the conversion of triglycerides into ethyl esters (biodiesel). The different cases are shown in Tables 1(I, II, II), 2(I, II, III), and 3(I, II, III). Tables 1, 2, and 3 refer to the DWSIM ${ }^{\circledR}$ material balance data for the process, the operating conditions and compositions of the extraction column supply and outlet streams, and the operational conditions and compositions of purified biodiesel streams using the different strategies. The experimental data used were from a previous study in Vilas Bôas et al. (2020).

\subsection{Different lipid raw materials}

Material and energy balance for the simulated process of biodiesel production from vegetable oil deodorization distillate (VODD) are shown in Table 1 (I, II, and III). Commercial soybean oil was also used as a raw material in a comparative way. The flow numbers in the three tables are in accordance with the DWSIM ${ }^{\circledR}$ process model shown in Figure 1 , starting from the oil stream to the biodiesel product stream.

All the cases studied followed the same configuration, being the oil mixed with alcohol, and the mixture is heated to the reaction temperature. This procedure was adopted so that it was possible to simulate a reactor operating isothermally. The 
reactions were carried out with a molar ratio of 1:9 of oil/ethanol, using HT-HAp as a catalyst (5\% wt.) and $101 \mathrm{kPa}$ in the CSTR-01 reactor.

In general, it was possible to observe that simulations results were similar to the experimental ones, emphasizing the separation of the two phases by the liquid-liquid extractor.

As shown in Table 1, the main differences between the two simulated cases are related to the different raw materials in respect to the composition of the oil stream at the reactor inlet. Table 1(I) shows the results of the simulations, using VODD and commercial soy oil as lipid raw materials in order to evaluate the conversion, and compare it with the use of different types of raw materials. Therefore, the conversion of the first reaction using the raw material VODD was approximately $91 \%$, while using the raw material commercial soybean oil the value obtained was $86 \%$. These results showed that the chemical catalyst (HT-HAp) was able to form the main esters of fatty acids even in different lipid sources used, providing values ranging from 86 to $91 \%$. The results obtained also demonstrated the adequacy of the residual raw material used to produce biodiesel, obtaining a high conversion into ethyl esters.

On the other hand, in the configuration of the -SC extraction column, similar results were generated for both simulations using the different raw materials (Table 1(II)). In which, the SC was converged with a reflux ratio 6 . Therefore, in the absence of experimental data, the use of the UNIFAC method can be considered an adequate alternative for the estimation of the interaction parameters of the thermodynamic model chosen to represent the behavior of the liquid-liquid equilibrium the two phases as biodiesel and glycerol (Sajid; Khan; Zhang, 2016). Then, the solid catalyst (HT-HAp) and the excess alcohol were separated from the SC in MSTR-07 (Figure 1a) and MSTR-08 (Figure 1c) to obtain glycerol with 99\% purity. In the purification stage, the biodiesel was obtained as the bottom flow of the CS-02 with $100 \%$ recovery and approximately $86-91 \%$ purity, depending on the type of raw material used in the process.

In relation, the differences observed in the results obtained in the biodiesel purification stage (Table 1(III)) could be explained by the addition of components and the thermodynamic package; there were observed differences between the values of the binary interaction parameters for the two simulations. This probably occurred because the parameters of binary interaction affect the balance of the phases, and consequently cause differences in the values of the biodiesel purification step (Santana et al., 2016).

The results obtained using DWSIM ${ }^{\circledR}$ had similar behaviours with other already published using different types of commercial simulators. Chilev and Simeonov (2014) used the ChemCAD ${ }^{\circledR}$ simulator in their work to simulate the production of biodiesel from pure vegetable oil as raw material using $\mathrm{NaOH}$ as a catalyst, obtaining $99.4 \%$ of conversion. On the other hand, Okulli and Tibasiima (2017) investigated a biodiesel production process from Jatropha curcas seed oil using $\mathrm{NaOH}$ catalyst (1\% wt.) in a 1:6 molar ratio of oil/methanol. The process was designed and simulated in HYSYS $^{\circledR}$ reaching high conversions of biodiesel (99\%). Similar results were obtained by Souza et al. (2020) studying a biodiesel process using the Aspen Plus ${ }^{\circledR}$ simulator using palm oil as raw material and $\mathrm{NaOH}$ as a catalyst in a 6:1 molar ratio of ethanol/oil and reaction temperatures between 60 and $80^{\circ} \mathrm{C}$, obtaining biodiesel conversions up to $96 \%$. 
Research, Society and Development, v. 10, n. 6, e15210615452, 2021

(CC BY 4.0) | ISSN 2525-3409 | DOI: http://dx.doi.org/10.33448/rsd-v10i6.15452

Table 1(I). Material balance data from DWSIM ${ }^{\circledR}$ for the process using different lipid raw materials.

\begin{tabular}{|c|c|c|c|c|c|c|}
\hline \multirow[b]{3}{*}{ Stream number } & \multicolumn{3}{|c|}{ VODD } & \multicolumn{3}{|c|}{$\begin{array}{l}\text { Soy oil } \\
\end{array}$} \\
\hline & \multicolumn{2}{|c|}{ Input } & \multirow{2}{*}{$\begin{array}{c}\text { Output } \\
\text { Mixture resulting in the } \\
\text { reaction (M1) }\end{array}$} & \multicolumn{2}{|c|}{ Input } & \multirow{2}{*}{$\begin{array}{c}\text { Output } \\
\begin{array}{c}\text { Mixture resulting in the } \\
\text { reaction (M1) }\end{array}\end{array}$} \\
\hline & Oil & Ethanol + HT-HAp & & Oil & Ethanol + HT-HAp & \\
\hline Temperature, ${ }^{\circ} \mathrm{C}$ & 70 & 70 & 70 & 70 & 70 & 72.05 \\
\hline Pressure, $\mathrm{kPa}$ & 101.33 & 101.33 & 101.33 & 101.33 & 101.33 & 101.33 \\
\hline Molar Flow, mol/s & 139.67 & 1346.13 & 1433.38 & 139.67 & 1326.52 & 1441.4 \\
\hline Mass Flow, $\mathrm{kg} / \mathrm{s}$ & 38.58 & 159.93 & 198.51 & 38.75 & 160.51 & 199.26 \\
\hline Liquid Volume Flow, $\mathrm{m}^{3} / \mathrm{s}$ & 0.0334 & 3.32 & 3.94 & 0.0323 & 3.60 & 6.21 \\
\hline Specific Enthalpy, kJ/kg & -463.71 & -289.03 & -332.45 & -757.70 & -285.44 & -305.701 \\
\hline \multicolumn{7}{|l|}{ Component Mole fraction } \\
\hline Linoleic acid (Oil) & 0.97 & - & 0.0117 & 0.97 & - & 0.0067 \\
\hline Oleic acid (Oil) & - & - & - & 0.97 & - & 0.0108 \\
\hline E- Linoleate (Biodiesel) & 0.01 & - & 0.0763 & 0.01 & - & 0.0270 \\
\hline E-Oleate (Biodiesel) & - & - & - & 0.01 & - & 0.0432 \\
\hline Glycerol & 0.01 & - & 0.0160 & 0.02 & - & 0.0132 \\
\hline HT-HAp & - & 0.0521 & 0.0482 & - & 0.0524 & 0.0482 \\
\hline $\mathrm{H}_{2} \mathrm{O}$ & 0.01 & - & 0.0010 & 0.02 & - & 0.0010 \\
\hline
\end{tabular}

Table 1(II). Operating conditions and compositions of the supply and output currents of the extraction column.

\begin{tabular}{|c|c|c|c|c|c|c|}
\hline \multirow{3}{*}{ Stream number } & \multicolumn{3}{|c|}{ VODD } & \multicolumn{3}{|c|}{ Soy oil } \\
\hline & \multirow{2}{*}{$\begin{array}{c}\text { Input } \\
\mathrm{M}_{2}\end{array}$} & \multicolumn{2}{|c|}{ Output } & \multirow{2}{*}{$\begin{array}{c}\text { Input } \\
\mathrm{M}_{2}\end{array}$} & \multicolumn{2}{|c|}{ Output } \\
\hline & & Top & Bottom & & Top & Bottom \\
\hline Temperature, ${ }^{\circ} \mathrm{C}$ & 64.62 & 2.31 & 230.73 & 72.05 & 2.94 & 437.5 \\
\hline Pressure, $\mathrm{kPa}$ & 101.33 & 101.33 & 101.33 & 101.33 & 101.33 & 101.33 \\
\hline Molar Flow, mol/s & 1435.62 & 1333.78 & 101.858 & 1441.4 & 1359.66 & 81.81 \\
\hline Mass Flow, kg/s & 198.51 & 167.52 & 30.99 & 199.26 & 174.46 & 24.81 \\
\hline Liquid Volume Flow, $\mathrm{m}^{3} / \mathrm{s}$ & 6.09 & 0.1942 & 0.0430 & 6.21 & 0.2015 & 0.0344 \\
\hline Specific Enthalpy, kJ/kg & -332.41 & -394.47 & 56.08 & -305.701 & -404.68 & 53.56 \\
\hline \multicolumn{7}{|l|}{ Component Mole fraction } \\
\hline Ethanol & 0.8476 & 0.9123 & 0.0001 & 0.8499 & 0.9011 & 0.0001 \\
\hline Linoleic acid (Oil) & 0.0173 & 0.0090 & 0.1271 & 0.0067 & 0.0053 & 0.0307 \\
\hline Oleic acid (Oil) & - & - & & 0.0108 & 0.0004 & 0.1831 \\
\hline E- Linoleate (Biodiesel) & 0.0710 & 0.01 & 0.8697 & 0.0270 & 0.01 & 0.3103 \\
\hline E-Oleate (Biodiesel) & - & - & - & 0.0432 & 0.0172 & 0.4737 \\
\hline Glycerol & 0.0148 & 0.0160 & 0.0030 & 0.0132 & 0.0139 & 0.0014 \\
\hline HT-HAp & 0.0481 & 0.0520 & $7.96 \mathrm{E}-10$ & 0.0482 & 0.0511 & $1.56 \mathrm{E}-09$ \\
\hline $\mathrm{H}_{2} \mathrm{O}$ & 0.0010 & 0.0010 & $1.10 \mathrm{E}-07$ & 0.0010 & 0.0010 & $1.11 \mathrm{E}-07$ \\
\hline
\end{tabular}


Research, Society and Development, v. 10, n. 6, e15210615452, 2021

(CC BY 4.0) | ISSN 2525-3409 | DOI: http://dx.doi.org/10.33448/rsd-v10i6.15452

Table 1(III). Operational conditions and compositions of purified biodiesel streams.

\begin{tabular}{lcc}
\multicolumn{1}{c}{$\begin{array}{c}\text { Biodiesel } \\
\text { Purified }\end{array}$} & VODD & Soy oil \\
\hline Temperature, ${ }^{\circ} \mathrm{C}$ & 437.5 & 437.5 \\
Pressure, $\mathrm{kPa}$ & 100.29 & 100.29 \\
Molar Flow, mol/s & 101.82 & 81.62 \\
Mass Flow, kg/s & 30.99 & 24.80 \\
Liquid Volume Flow, $\mathrm{m}^{3} / \mathrm{s}$ & 0.0371 & 0.0297 \\
Specific Enthalpy, kJ/kg & 647.66 & 650.20 \\
\hline Component Mole fraction & & \\
\hline Ethanol & - & - \\
Linoleic acid (Oil) & 0.1272 & 0.0307 \\
Oleic acid (Oil) & - & 0.1835 \\
E- Linoleate (Biodiesel) & 0.9100 & 0.3110 \\
E-Oleate (Biodiesel) & - & 0.5547 \\
Glycerol & 0.0030 & $1.70 \mathrm{E}-019$ \\
HT-HAp & - & - \\
$\mathrm{H}_{2} \mathrm{O}$ & - & - \\
\hline
\end{tabular}

Source: Authors.

\subsection{Different catalysts}

The comparisons between the use of hydrotalcite-hydroxyapatite (HT-HAp) and sodium hydroxide (NaOH) as a catalyst in the production of biodiesel were also investigated. The comparative results can be seen in Table 2(I, II, and III), in which they refer to the DWSIM ${ }^{\circledR}$ material balance data for the process, the operational conditions and compositions of the extraction column feed and output flows and the operational conditions and compositions of purified biodiesel flows.

The reactions were carried out using a 1:9 molar ratio of VODD/ethanol for the 2 catalysts with a concentration of 5\% in relation to the reaction medium, at $70{ }^{\circ} \mathrm{C}$ and $101 \mathrm{kPa}$ in the CSTR-01 reactor. As shown in Table 2, the main differences between the two simulated cases are related to the use of different catalysts. Thus, Table 2(I) shows the results of the simulations, showing that the conversion of the reactions using the heterogeneous catalyst HT-HAp was approximately $91 \%$ while using $\mathrm{NaOH}$ it was obtained a higher conversion of $99.7 \%$ in ethyl esters (biodiesel). This result can confirm the wide application of the $\mathrm{NaOH}$ as catalyst in most of the biodiesel production processes. The high conversion relies on the fact that the alkoxide ion is produced in situ to then promote the nucleophilic attack on the acyl glycerol carbonyl (Patel \& Sankhavara, 2017). Although this process provides high yields on alkyl monoesters, under ideal reaction conditions, the subsequent purification steps are quite costly due to the monoesters and, mainly, the glycerine obtained as a by-product in the process, presenting contamination with salts, acyl glycerol, soaps, among others. others. This fact requires the execution of several unit purification operations, which increases capital investment and, therefore, makes the process more expensive (Baskar \& Aiswarya, 2016). Because of that, it is necessary to do an economic evaluation of the complex treatment systems of glycerol.

Meanwhile, biodiesel synthesis using heterogeneous catalysts offer technical and environmental advantages over homogeneous catalysis, as it facilitates the purification of alkyl monoesters and glycerol, as well. This allows the recycling of the solid catalyst throughout its useful life and minimizes the generation of effluents. In addition, it facilitates the recovery and purification of glycerin considerably (Ruhul et al., 2015). Several solids have been proposed as potential catalysts for the synthesis of biodiesel. The performance of these materials as catalysts is naturally related to the nature of the acidic or basic sites found in these materials (Vilas Bôas et al., 2020).

According to Table 2(II), it was possible to observe that the configuration of the -SC extraction column generated similar results using the 2 catalysts. In which, SC was converged with reflux ratio 6. Meanwhile, the catalyst and excess 
Research, Society and Development, v. 10, n. 6, e15210615452, 2021

(CC BY 4.0) | ISSN 2525-3409 | DOI: http://dx.doi.org/10.33448/rsd-v10i6.15452

alcohol were separated from the SC in MSTR-07 (Figure 1 (a and b)) obtaining glycerol with 99\% purity. On the other hand, in the purification stage (Table 2(III)), the biodiesel product was obtained through the bottom flow of the CS-02 with 100\% recovery and approximately $91-99 \%$ purity, depending on the type of catalyst used in the process. Thus, it was demonstrated that heterogeneous catalysts had great potential to replace the homogeneous systems currently used in the biodiesel industry and this substitution offers advantages, which provide a considerable increase in the prospects for socio-environmental sustainability of the entire production process.

It was not possible to compare these results with other already published in the literature since there are not similar using the same catalyst. However, there are similar ones that used also heterogeneous catalysts. Abdurakhman, Putra \& Bilad (2017) investigated the production of biodiesel from residual cooking oil and methanol using WAl (synthesized tungsten on alumina supported catalyst) as heterogeneous catalyst. The biodiesel production process was simulated using Aspen HYSYS, using the following conditions: temperature $110{ }^{\circ} \mathrm{C}$, pressure $11.51 \mathrm{bar}$, concentration of catalyst WAl $1 \%$ (wt.), and molar ratio of 0.3 methanol/oil. The reactor used in the simulated process was a membrane reactor, where the permeate stream, containing the biodiesel, was drawn from the membrane reactor while retentate is recycled back to the reactor. In the permeate, the phases formed were FAME and glycerol. The methanol present in the FAME phase was separated using a distillation column, and then recycled to the methanol storage tank. The final product of the distillation column was fed to the second distillation column, where the separation of FAME and FFA occurred. The FAME (biodiesel) was recovered in the distillate flow from the second distillation column. The simulated process obtained a conversion to $97.5 \%$ methyl esters. Thus, confirming that heterogeneous catalysts are preferable for transesterification processes when residual raw materials are used.

More recently, Cagatay and Karacan (2018) investigated the production of biodiesel in a continuous flow in a reactive column (RD) of distillation. In this study, the authors carried out a continuous flow simulation of biodiesel production (FAME) on a packed RD column with the heterogeneous $\mathrm{CaO}$ catalyst using the Aspen HYSYS 3.2 software, using a low-cost residual cooking oil and methanol. The optimum conditions were determined with a reflux ratio of 0.1 , a feed flow rate of $11.2 \times 10^{-4}$ kgmol.h ${ }^{-1}$, and a methanol/oil molar ratio of 6.42 to obtain a maximum conversion of $99.97 \%$.

\subsection{Different molar ratios of oil/alcohol}

The reactions were performed with different molar ratios of 1:6, 1:12, and 1:45 of VODD/ethanol, using HT-HAp as a catalyst (5\% wt.) at $70{ }^{\circ} \mathrm{C}$ and $101 \mathrm{kPa}$ in the CSTR-01 reactor. Material and energy balance tables for the simulated biodiesel production process using the different molar ratios are shown in Table 3(I, II, and III). The results show that the simulation developed in this strategy presents values close to those of the literature.

Table 3(I) shows the results of the simulations, aiming to evaluate the conversions and compare them with the use of different molar ratios of VODD/ethanol. Therefore, the conversion of the reactions using the molar ratios of 1:6 and 1:12 of oil/alcohol was approximately $89-91 \%$ while using the 1:45 molar ratio of oil/alcohol obtained a higher conversion of $97 \%$ in ethyl esters (biodiesel).

The extraction step in the simulation generated similar results for both cases using the different molar ratios (Table 3 (II)), converging with a reflux ratio of 6. Meanwhile, the solid catalyst (HT-HAp) and the excess of alcohol were separated from the SC in MSTR-07 (Figure 1a) to obtain glycerol with 99\% purity. While, in the purification stage (Table 3 (III)), the biodiesel product achieved $100 \%$ recovery and approximately $89-97 \%$ purity (CS-02 flow). 
Research, Society and Development, v. 10, n. 6, e15210615452, 2021

(CC BY 4.0) | ISSN 2525-3409 | DOI: http://dx.doi.org/10.33448/rsd-v10i6.15452

Table 2(I). Material balance data from DWSIM ${ }^{\circledR}$ for the process using different types of catalysts.

\begin{tabular}{|c|c|c|c|c|c|c|}
\hline \multirow[b]{3}{*}{ Stream number } & \multicolumn{3}{|c|}{ HT-HAр } & \multicolumn{3}{|c|}{$\mathrm{NaOH}$} \\
\hline & \multicolumn{2}{|c|}{ Input } & \multirow{2}{*}{$\begin{array}{c}\text { Output } \\
\text { Mixture resulting in the } \\
\text { reaction (M1) }\end{array}$} & \multicolumn{2}{|c|}{ Input } & \multirow{2}{*}{$\begin{array}{c}\text { Output } \\
\text { Mixture resulting in the } \\
\text { reaction (M1) }\end{array}$} \\
\hline & Oil & Ethanol + HT-HAp & & Oil & Ethanol $+\mathrm{NaOH}$ & \\
\hline Temperature, ${ }^{\circ} \mathrm{C}$ & 70 & 70 & 70 & 70 & 70 & 70 \\
\hline Pressure, $\mathrm{kPa}$ & 101.33 & 101.33 & 101.33 & 101.33 & 101.33 & 101.33 \\
\hline Molar Flow, mol/s & 139.67 & 1346.13 & 1433.38 & 129.53 & 1234.97 & 1330.31 \\
\hline Mass Flow, kg/s & 38.58 & 159.93 & 198.51 & 35.78 & 56.47 & 92.24 \\
\hline Liquid Volume Flow, $\mathrm{m}^{3} / \mathrm{s}$ & 0.0334 & 3.32 & 3.94 & 0.0309 & 0.0704 & 0.1074 \\
\hline Specific Enthalpy, kJ/kg & -463.71 & -289.03 & -332.45 & -463.708 & -1071.52 & -864.17 \\
\hline \multicolumn{7}{|l|}{ Component Mole fraction } \\
\hline Ethanol & - & 0.9479 & 0.8468 & - & 0.9439 & 0.8421 \\
\hline Linoleic acid (Oil) & 0.97 & - & 0.0117 & 0.97 & - & 0.0003 \\
\hline E- Linoleate (Biodiesel) & 0.01 & - & 0.0763 & 0.01 & - & 0.0865 \\
\hline Glycerol & 0.01 & - & 0.0160 & 0.01 & - & 0.0180 \\
\hline $\mathrm{H}_{2} \mathrm{O}$ & 0.01 & - & 0.0010 & 0.01 & - & 0.0001 \\
\hline $\mathrm{NaOH}$ & - & - & - & - & 0.0560 & 0.0521 \\
\hline HT-HAp & - & 0.0521 & 0.0482 & - & - & - \\
\hline
\end{tabular}

Table 2(II). Operating conditions and compositions of the supply and output currents of the extraction column.

\begin{tabular}{|c|c|c|c|c|c|c|}
\hline \multirow{3}{*}{ Stream number } & \multicolumn{3}{|c|}{ HT-HAp } & \multicolumn{3}{|c|}{$\mathrm{NaOH}$} \\
\hline & \multirow{2}{*}{$\begin{array}{c}\text { Input } \\
\mathrm{M}_{2} \\
\end{array}$} & \multicolumn{2}{|c|}{ Output } & \multirow{2}{*}{$\begin{array}{c}\text { Input } \\
\mathrm{M}_{2} \\
\end{array}$} & \multicolumn{2}{|c|}{ Output } \\
\hline & & Top & Bottom & & Top & Bottom \\
\hline Temperature, ${ }^{\circ} \mathrm{C}$ & 64.62 & 2.31 & 230.73 & 49.5 & 79.5 & 230.73 \\
\hline Pressure, $\mathrm{kPa}$ & 101.33 & 101.33 & 101.33 & 101.33 & 101.33 & 101.33 \\
\hline Molar Flow, mol/s & 1435.62 & 1333.78 & 101.858 & 1330.31 & 1160.59 & 169.72 \\
\hline Mass Flow, kg/s & 198.51 & 167.52 & 30.99 & 92.25 & 57.58 & 34.67 \\
\hline Liquid Volume Flow, $\mathrm{m}^{3} / \mathrm{s}$ & 6.09 & 0.1942 & 0.0430 & 0.1074 & 0.0781 & 0.0258 \\
\hline Specific Enthalpy, kJ/kg & 648.04 & -394.47 & 56.08 & -864.17 & -769.15 & $-233,19$ \\
\hline \multicolumn{7}{|l|}{ Component Mole fraction } \\
\hline Ethanol & 0.8476 & 0.9123 & 0.0001 & 0.8420 & 0.9652 & 0.0001 \\
\hline Linoleic acid (Oil) & 0.0173 & 0.0090 & 0.1271 & 0.0003 & 0.0001 & 0.0016 \\
\hline E- Linoleate (Biodiesel) & 0.0710 & 0.0100 & 0.8697 & 0.0865 & 0.0100 & 0.6098 \\
\hline Glycerol & 0.0148 & 0.0160 & 0.0030 & 0.0181 & 0.0203 & 0.0029 \\
\hline $\mathrm{H}_{2} \mathrm{O}$ & 0.0010 & 0.0010 & $1.10 \mathrm{E}-07$ & 0.0001 & 0.0010 & $1.12 \mathrm{E}-07$ \\
\hline $\mathrm{NaOH}$ & - & - & - & 0.0521 & 0.0033 & 0.3856 \\
\hline HT-HAp & 0.0481 & 0.0520 & 7.96E-10 & - & - & - \\
\hline
\end{tabular}


Research, Society and Development, v. 10, n. 6, e15210615452, 2021

(CC BY 4.0) | ISSN 2525-3409 | DOI: http://dx.doi.org/10.33448/rsd-v10i6.15452

Table 2(III). Operational conditions and compositions of purified biodiesel streams.

\begin{tabular}{lcc}
\multicolumn{1}{c}{$\begin{array}{c}\text { Biodiesel } \\
\text { Purified }\end{array}$} & HT-HAp & NaOH \\
\hline Temperature, ${ }^{\circ} \mathrm{C}$ & 437.50 & 437.50 \\
Pressure, $\mathrm{kPa}$ & 100.29 & 100.29 \\
Molar Flow, mol/s & 101.82 & 103.76 \\
Mass Flow, kg/s & 30.99 & 32.01 \\
Liquid Volume Flow, m ${ }^{3 / \mathrm{s}}$ & 0.0371 & 0.0377 \\
Specific Enthalpy, kJ/kg & 647.66 & 648.52 \\
\hline Component Mole fraction & & - \\
& - & 0.0026 \\
Ethanol & 0.0862 & 0.9974 \\
Linoleic acid (Oil) & 0.9138 & 0.0004 \\
E- Linoleate (Biodiesel) & $5.26 \mathrm{E}-19$ & - \\
Glycerol & - & - \\
HT-HAp & - & - \\
NaOH & - & \\
H ${ }_{2} \mathrm{O}$ & \multicolumn{2}{c}{} \\
\hline
\end{tabular}

Source: Authors.

In general, the results could show that the excess of alcohol guarantees the formation of the catalyst-acyl group complex for subsequent reaction with oil, leading the formation of ethyl esters, and thus competition among acceptors, an essential parameter for the kinetics of a transesterification reaction (Verma \& Sharma, 2016). It is necessary that the synthesis of biodiesel catalysed by hydrotalcite-hydroxyapatite (HT-HAp) can be limited by the concentration of alcohol, suggesting the application of higher molar ratios for the higher production of of ethyl esters (biodiesel). Therefore, with the increase in the molar ratio (alcohol/oil), a conversion gradually increases. It was also verified that conversions higher than $95 \%$ needs molar ration between alcohol/oil higher than 1:40.

This behaviour can be compared to the results of Cruz, Ferreira and Rodrigues (2017). The authors simulated a plant using homogeneous acid catalysit, in which a 50:1 alcohol/oil molar ratio and a 1.3:1 catalyst/oil ratio were used. The simulated process consisted of ethanol and macauba oil in a conversion reactor, operating at $80{ }^{\circ} \mathrm{C}$ with a flow rate of 1000 $\mathrm{kg} \cdot \mathrm{h}^{-1}$. The process was simulated in Aspen HYSYS 8.8 and obtained purified biodiesel with $99.8 \%$ purity. Since the theoretical amount of ethanol required (3:1 ethanol/oil) is much less than the amount used (50:1), there is a large amount of unreacted ethanol after the reaction step, so the authors used the recycling strategy to reduce operating costs. In this way, they used a distillation column (T-100) to separate this ethanol and send it for recycling. The column was designed to operate with five stages and a reflux rate of two. It was possible to recover $93.83 \%$ of unreacted ethanol, with a purity of $99.02 \%$. Therefore, the use of residual raw material and the insertion of the recycling strategy for unreacted ethanol in the plant can significantly impact cost reduction. 
In relation to the comparison between the experimental and numerical results, the standard deviation of the conversion into ethyl esters, experimental and numerical, was

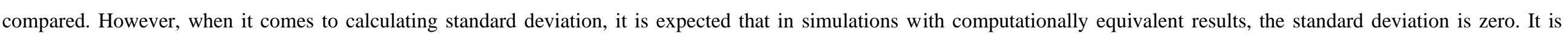

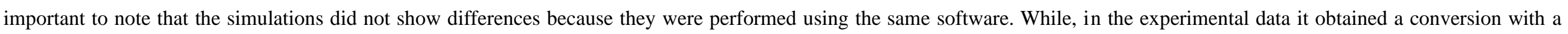

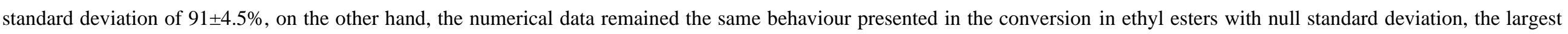

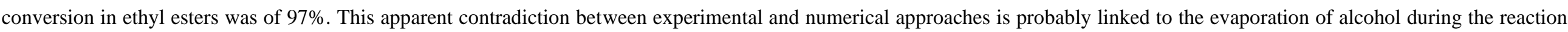

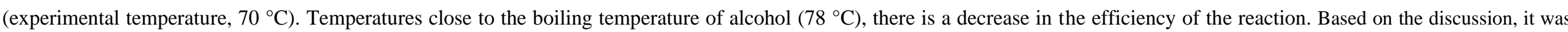

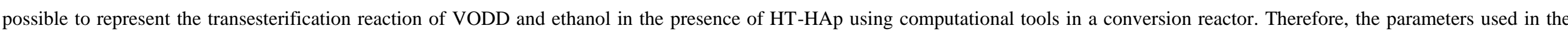
simulations showed similar reaction behaviour when compared with experimental results.

Table 3(I). Material balance data from DWSIM ${ }^{\circledR}$ for the process using different molar rations of oil/alcohol.

\begin{tabular}{|c|c|c|c|c|c|c|c|c|c|}
\hline \multirow[b]{3}{*}{ Stream number } & \multicolumn{3}{|c|}{ RM 1:6 } & \multicolumn{3}{|c|}{ RM 1:12 } & \multicolumn{3}{|c|}{ RM 1:45 } \\
\hline & \multicolumn{2}{|c|}{ Input } & \multirow{2}{*}{$\begin{array}{c}\text { Output } \\
\begin{array}{c}\text { Mixture resulting in the } \\
\text { reaction (M1) }\end{array}\end{array}$} & \multicolumn{2}{|c|}{ Input } & \multirow{2}{*}{$\begin{array}{c}\text { Output } \\
\begin{array}{c}\text { Mixture resulting in the } \\
\text { reaction (M1) }\end{array}\end{array}$} & \multicolumn{2}{|c|}{ Input } & \multirow{2}{*}{$\begin{array}{c}\text { Output } \\
\text { Mixture resulting in the } \\
\text { reaction (M1) }\end{array}$} \\
\hline & Oil & $\begin{array}{c}\text { Ethanol + HT- } \\
\text { HAp }\end{array}$ & & Oil & $\begin{array}{c}\text { Ethanol + HT- } \\
\text { HAp }\end{array}$ & & Oil & $\begin{array}{c}\text { Ethanol + HT- } \\
\text { HAp }\end{array}$ & \\
\hline Temperature, ${ }^{\circ} \mathrm{C}$ & 70 & 70 & 70 & 70 & 70 & 70 & 70 & 70 & 70 \\
\hline Pressure, $\mathrm{kPa}$ & 101.33 & 101.33 & 101.33 & 101.33 & 101.33 & 101.33 & 101.33 & 101.33 & 101.33 \\
\hline Molar Flow, mol/s & 139.67 & 887.63 & 994.03 & 139.67 & 1785.19 & 1893.85 & 37.24 & 1764.79 & 1793.31 \\
\hline Mass Flow, kg/s & 38.58 & 110.98 & 149.56 & 38.58 & 238.36 & 276.94 & 10.29 & 208.25 & 218.537 \\
\hline Liquid Volume Flow, $\mathrm{m}^{3} / \mathrm{s}$ & 0.0333 & 2.244 & 2.5904 & 0.3333 & 4.76 & 6.00 & 0.0089 & 4.3938 & 5.3816 \\
\hline Specific Enthalpy, kJ/kg & -463.71 & -277.81 & -337.29 & -463.71 & -258.58 & -294.11 & -327.75 & -295.95 & -300.44 \\
\hline \multicolumn{10}{|l|}{ Component Mole fraction } \\
\hline Ethanol & - & 0.9448 & 0.7991 & - & 0.9389 & 0.8632 & - & 0.9497 & 0.9281 \\
\hline Linoleic acid (Oil) & 0.97 & - & 0.0136 & 0.97 & - & 0.0115 & 0.97 & - & 0.0023 \\
\hline E- Linoleate (Biodiesel) & 0.01 & - & 0.1129 & 0.01 & - & 0.0553 & 0.01 & - & 0.0164 \\
\hline Glycerol & 0.01 & - & 0.0237 & 0.01 & - & 0.0117 & 0.01 & - & 0.0035 \\
\hline HT-HAp & 0 & 0.0552 & 0.0493 & 0 & 0.0611 & 0.0576 & 0 & 0.0503 & 0.0495 \\
\hline $\mathrm{H}_{2} \mathrm{O}$ & 0.01 & - & 0.0014 & 0.01 & - & 0.0007 & 0.01 & - & 0.0002 \\
\hline
\end{tabular}


Research, Society and Development, v. 10, n. 6, e15210615452, 2021

(CC BY 4.0) | ISSN 2525-3409 | DOI: http://dx.doi.org/10.33448/rsd-v10i6.15452

Table 3(II). Operating conditions and compositions of the supply and output currents of the extraction column.

\begin{tabular}{|c|c|c|c|c|c|c|c|c|c|}
\hline \multirow[b]{3}{*}{ Stream number } & \multicolumn{3}{|c|}{ RM 1:6 } & \multicolumn{3}{|c|}{ RM 1:12 } & \multicolumn{3}{|c|}{ RM 1:45 } \\
\hline & \multicolumn{2}{|c|}{ Input } & \multirow{2}{*}{$\begin{array}{l}\text { Output } \\
\text { Bottom } \\
\end{array}$} & \multicolumn{2}{|c|}{ Input } & \multirow{2}{*}{$\begin{array}{l}\text { Output } \\
\text { Bottom } \\
\end{array}$} & \multicolumn{2}{|c|}{ Input } & \multirow{2}{*}{$\begin{array}{l}\text { Output } \\
\text { Bottom }\end{array}$} \\
\hline & $\mathrm{M}_{2}$ & Top & & $\mathrm{M}_{2}$ & Top & & $\mathrm{M}_{2}$ & Top & \\
\hline Temperature, ${ }^{\circ} \mathrm{C}$ & 63.97 & 0.01 & 230.73 & 63.31 & 3.2 & 267.85 & 63.99 & 3.749 & 437.51 \\
\hline Pressure, $\mathrm{kPa}$ & 101.33 & 101.33 & 101.33 & 101.33 & 101.33 & 101.33 & 101.33 & 101.33 & 101.33 \\
\hline Molar Flow, mol/s & 994.03 & 881.13 & 112.91 & 1893.85 & 1797.24 & 96.62 & 1793.31 & 1781.27 & 12.04 \\
\hline Mass Flow, kg/s & 149.56 & 115.10 & 34.46 & 276.94 & 247.46 & 29.48 & 218.537 & 214.84 & 3.70 \\
\hline Liquid Volume low, $\mathrm{m}^{3} / \mathrm{s}$ & 2.5904 & 0.1401 & 0.0318 & 6.00 & 0.3020 & 0.0273 & 5.3816 & 0.2517 & 0.0051 \\
\hline Specific Enthalpy, kJ/kg & -337.29 & -378.74 & 55.55 & -294.11 & -356.88 & 56.32 & -300.44 & -395.55 & 57.02 \\
\hline \multicolumn{10}{|l|}{ Component Mole fraction } \\
\hline Ethanol & 0.7991 & 0.9015 & 0.0001 & 0.8632 & 0.9096 & 0.0001 & 0.9281 & 0.9344 & 0.0001 \\
\hline Linoleic acid (Oil) & 0.0136 & 0.0053 & 0.0790 & 0.0115 & 0.0068 & 0.0100 & 0.0023 & 0.0021 & 0.0329 \\
\hline E- Linoleate (Biodiesel) & 0.1129 & 0.01 & 0.9160 & 0.0553 & 0.01 & 0.8976 & 0.0164 & 0.01 & 0.9660 \\
\hline Glycerol & 0.0237 & 0.0261 & 0.0048 & 0.0117 & 0.0122 & 0.0021 & 0.0035 & 0.0035 & 0.0006 \\
\hline HT-HAp & 0.0493 & 0.0556 & $1.828 \mathrm{E}-09$ & 0.0576 & 0.0607 & $2.224 \mathrm{E}-09$ & 0.0495 & 0.0498 & $1.4881 \mathrm{E}-09$ \\
\hline $\mathrm{H}_{2} \mathrm{O}$ & 0.0014 & 0.0016 & $1.736 \mathrm{E}-07$ & 0.0007 & 0.0008 & 8.027E-08 & 0.0002 & 0.0002 & $2.016 \mathrm{E}-08$ \\
\hline
\end{tabular}

Table 3(III). Operational conditions and compositions of purified biodiesel streams.

\begin{tabular}{lccc}
\multicolumn{1}{c}{$\begin{array}{c}\text { Biodiesel } \\
\text { Purified }\end{array}$} & RM 1:6 & RM 1:12 & RM 1:45 \\
\hline Temperature, ${ }^{\circ} \mathrm{C}$ & 437.5 & 437.5 & 437.5 \\
Pressure, $\mathrm{kPa}$ & 100.29 & 100.29 & 100.29 \\
Molar Flow, mol/s & 112.88 & 96.59 & 12.04 \\
Mass Flow, kg/s & 34.46 & 29.48 & 3.70 \\
Liquid Volume Flow, $\mathrm{m}^{3} / \mathrm{s}$ & 0.0410 & 0.0352 & 0.0044 \\
Specific Enthalpy. $\mathrm{kJ} / \mathrm{kg}$ & 647.17 & 647.82 & 648.33 \\
\hline Component Mole fraction & & & \\
\hline Ethanol & - & - & - \\
Linoleic acid (Oil) & 0.0791 & 0.0100 & 0.0329 \\
E- Linoleate (Biodiesel) & 0.9162 & 0.8979 & 0.9765 \\
Glycerol & 0.0048 & 0.0022 & 0.0006 \\
HT-HAp & - & - & - \\
$\mathrm{H}_{2} \mathrm{O}$ & - & - & - \\
\hline
\end{tabular}

Source: Authors. 


\section{Conclusion}

In this study, a heterogeneous catalyst (hydrotalcite-hydroxyapatite - HT-HAp) was used in the simulation of the biodiesel production from vegetable oil deodorizing distillate (VODD). The results showed that the chemical catalyst (HTHAp) was able to form the main esters of fatty acids even using different strategies, providing conversions varying between 86 to $97 \%$. Among the main differences between the simulated cases, it is important to highlight the different molar ratios of alcohol/oil, revealing that the excess of alcohol guarantees a high conversion of ethyl esters. Therefore, high conversions (> 90\%) of reaction were reached applying also higher molar ratios between alcohol and oil. Moreover, the experimental and simulated results were similar, confirming the potential of the simulator to represent the kinetic of the transesterification reaction.

\section{Acknowledgments}

This work was supported by the Research Support Foundation of the State of Rio de Janeiro (FAPERJ) and Coordenação de Aperfeiçoamento de Pessoal de Nível Superior (CAPES - Finance Code 001).

\section{References}

Abdurakhman, Y. B., Putra, Z. A., \& Bilad, M. R. (2017). Process simulation and economic analysis of biodiesel production from waste cooking oil with membrane bioreactor. In: AIP Conference Proceedings. AIP Publishing LLC, 1891(1), 020011. https://doi.org/10.1063/1.5005344

Aboelazayem, O., Gadalla, M., \& Saha, B. (2018). Design and simulation of an integrated process for biodiesel production from waste cooking oil using supercritical methanolysis. Energy, 161, 299-307. https://doi.org/10.1016/j.energy.2018.07.139

Aghbashlo, M., Tabatabaei, M., Rastegari, H., \& Ghaziaskar, H. S. (2018). Exergy-based sustainability analysis of acetins synthesis through continuous esterification of glycerol in acetic acid using Amberlyst ${ }^{\circledR} 36$ as catalyst. Journal of Cleaner Production, 183 , $1265-1275$. https://doi.org/10.1016/j.jclepro.2018.02.218

ASTM D6751-15, Standard Specification for Biodiesel Fuel Blend Stock (B100) for Middle Distillate Fuels, ASTM Internacional, West Conshohocken, PA, 2015, www.astm.org.

Baskar, G., \& Aiswarya, R. (2016). Trends in catalytic production of biodiesel from various feedstocks. Renewable and Sustainable Energy Reviews, 57, 496504. https://doi.org/10.1016/j.rser.2015.12.101

Borugadda, V. B., \& Goud, V. V. (2012). Biodiesel production from renewable feedstocks: Status and opportunities. Renewable and Sustainable Energy Reviews, 16(7), 4763-4784. https://doi.org/10.1016/j.rser.2012.04.010

Brasil, H., Pereira, P., Corrêa, J., Nascimento, L., Rumjanek, V., Almeida, V., \& Rodrigues, E. (2017). Preparation of hydrotalcite-hydroxyapatite material and its catalytic activity for transesterification of soybean oil. Catalysis Letters, 147(2), 391-399. https://doi.org/10.1007/s10562-016-1961-9

Chen, G., Shan, R., Shi, J., Liu, C., \& Yan, B. (2015). Biodiesel production from palm oil using active and stable K doped hydroxyapatite catalysts. Energy Conversion and Management, 98, 463-469. https://doi.org/10.1016/j.enconman.2015.04.012

Chilev, C., \& Simeonov, E. (2014). Simulation of biodiesel production by transesterification of vegetable oils. Journal of Chemical Technology and Metallurgy, 49(5), 479-486.

Coral, N., Brasil, H., Rodrigues, E., Da Costa, C. E., \& Rumjanek, V. (2019). Microwave-modified hydrotalcites for the transesterification of soybean oil. Sustainable Chemistry and Pharmacy, 11, 49-53. https://doi.org/10.1016/j.scp.2019.01.002

Cruz, R. P., Ferreira, F. B., \& Rodrigues, F. D. Á. (2017). Simulation and economic analysis of biodiesel production from macauba oil. The Journal of Engineering and Exact Sciences, 3(3), 533-560. https://doi.org/10.18540/2446941603032017533

El-Galad, M. I. (2018). Techno-economic analysis of biodiesel production using co-solvent.

Essamlali, Y., Amadine, O., Larzek, M., Len, C., \& Zahouily, M. (2017). Sodium modified hydroxyapatite: Highly efficient and stable solid-base catalyst for biodiesel production. Energy Conversion and Management, 149, 355-367. https://doi.org/10.1016/j.enconman.2017.07.028

Giwa, A., \& Umanah, K. S. (2019). Optimization of Biodiesel Production from Used Cooking Oil: Aspen HYSYS Simulation and Experimental Validation. In: International Journal of Engineering Research in Africa. Trans Tech Publications Ltd, 43, 38-48. https://doi.org/10.4028/www.scientific.net/JERA.43.38

Guldhe, A., Singh, B., Mutanda, T., Permaul, K., \& Bux, F. (2015). Advances in synthesis of biodiesel via enzyme catalysis: Novel and sustainable approaches. Renewable and Sustainable Energy Reviews, 41, 1447-1464. https://doi.org/10.1016/j.rser.2014.09.035 
Research, Society and Development, v. 10, n. 6, e15210615452, 2021

(CC BY 4.0) | ISSN 2525-3409 | DOI: http://dx.doi.org/10.33448/rsd-v10i6.15452

Hanif, M. A., Nisar, S., Akhtar, M. N., Nisar, N., \& Rashid, N. (2018). Optimized production and advanced assessment of biodiesel: A review. International Journal of Energy Research, 42(6), 2070-2083. https://doi.org/10.1002/er.3990

Hussein, R. Z., Attia, N. K., Fouad, M. K., \& ElSheltawy, S. T. (2021). Experimental investigation and process simulation of biolubricant production from waste cooking oil. Biomass and Bioenergy, 144, 105850. https://doi.org/10.1016/j.biombioe.2020.105850

Karacan, S., \& Cagatay, M. T. (2018). Simulation and optimization of reactive packed distillation column for biodiesel production using heterogeneous catalyst. International Journal of Energy Applications and Technologies, 5(4), 153-160. https://doi.org/10.31593/ijeat.438001

Knothe, G. (2001). Analytical methods used in the production and fuel Quality Assessment of Biodiesel. Transaction of the American Society of Agricultural Engineers, 2(44), 193-200. https://doi.org/10.13031/2013.4740

Lee, A. F., \& Wilson, K. (2015). Recent developments in heterogeneous catalysis for the sustainable production of biodiesel. Catalysis Today, 242, 3-18. https://doi.org/10.1016/j.cattod.2014.03.072

Ma, F., \& Hanna, M. (1999). Biodiesel production: a review. Bioresource Technology, 70, 1-15. https://doi.org/10.1016/S0960-8524(99)00025-5

Medeiros, D. (2021). DWSIM Wiki. https://dwsim.inforside.com.br.

Micic, R. D., Tomic, M. D., Kiss, F. E., Martinovic, F. L., Simikic, M. D., \& Molnar, T. T. (2016). Comparative analysis of single-step and two-step biodiesel production using supercritical methanol on laboratory-scale. Energy Conversion and Management, $124, \quad 377-388$. https://doi.org/10.1016/j.enconman.2016.07.043

Morais, S., Mata, T. M., Martins, A. A., Pinto, G. A., \& Costa, C. A. (2010). Simulation and life cycle assessment of process design alternatives for biodiesel production from waste vegetable oils. Journal of Cleaner Production, 18(13), 1251-1259. https://doi.org/10.1016/j.jclepro.2010.04.014

Navajas, A., Campo, I., Moral, A., Echave, J., Sanz, O., Montes, M., Odriozola, J. A., Arzamendi, G., \& Gandía, L. M. (2018). Outstanding performance of rehydrated $\mathrm{Mg}-\mathrm{Al}$ hydrotalcites as heterogeneous methanolysis catalysts for the synthesis of biodiesel. Fuel, 211, 173-181. https://doi.org/10.1016/j.fuel.2017.09.061

Okullo, A., \& Noah, T. (2017). Process simulation of biodiesel production from jatropha curcas seed oil. American Journal of Chemical Engineering, 5(4), 5663. https://doi.org/10.11648/j.ajche.20170504.12

Patel, R. L., \& Sankhavara, C. D. (2017). Biodiesel production from Karanja oil and its use in diesel engine: A review. Renewable and Sustainable Energy Reviews, 71, 464-474. https://doi.org/10.1016/j.rser.2016.12.075

Rodrigues, E., Brasil, H., Barros, T., Pereira, C., Dos Reis, M. A. L., \& Almeida, O. (2018). Synthesis and characterization of hydrotalcite-hydroxyapatite material doped with carbon nanotubes and its application in. Cerâmica, 64, 166-175. https://doi.org/10.1590/0366-69132018643702230

Ruhul, A. M., Kalam, M. A., Masjuki, H. H., Fattah, I. R., Reham, S. S., \& Rashed, M. M. (2015). State of the art of biodiesel production processes: a review of the heterogeneous catalyst. RSC Advances, 5(122), 101023-101044. https://doi.org/10.1039/C5RA09862A

Sajid, Z., Khan, F., \& Zhang, Y. (2016). Process simulation and life cycle analysis of biodiesel production. Renewable Energy, 85, 945-952. https://doi.org/10.1016/j.renene.2015.07.046

Santana, H. S., Tortola, D. S., Reis, É. M., Silva Jr, J. L., \& Taranto, O. P. (2016). Transesterification reaction of sunflower oil and ethanol for biodiesel synthesis in microchannel reactor: Experimental and simulation studies. Chemical Engineering Journal, 302, 752-762. https://doi.org/10.1016/j.cej.2016.05.122

Sousa, M. R., Santana, H. S., \& Taranto, O. P. (2020). Modeling and simulation using OpenFOAM of biodiesel synthesis in structured microreactor. International Journal of Multiphase Flow, 132, 103435. https://doi.org/10.1016/j.ijmultiphaseflow.2020.103435

Souza, M. F., Hirata, G. F., \& Batista, E. A. (2020). Evaluation of kinetics and thermodynamic parameters for simulation of palm oil biodiesel production. Fluid Phase Equilibria, 525, 112792. https://doi.org/10.1016/j.fluid.2020.112792

Verma, P., \& Sharma, M. P. (2016). Review of process parameters for biodiesel production from different feedstocks. Renewable and Sustainable Energy Reviews, 62, 1063-1071. https://doi.org/10.1016/j.rser.2016.04.054

Vilas-Bôas, R. N., Da Silva, L. L., Fernandes, L. D., Augusto, B. L., \& Mendes, M. F. (2020). Study of the Use of Hydrotalcite-Hydroxyapatite as Heterogeneous Catalysts for Application in Biodiesel Using By-Product as Raw Material. Catalysis Letters, 150, 3642-3652. https://doi.org/10.1007/s10562020-03274-0

Wang, L., Du, W., Liu, D., Li, L., \& Dai, N. (2006). Lipase-catalyzed biodiesel production from soybean oil deodorizer distillate with absorbent present in tert-butanol system. Journal of Molecular Catalysis B: Enzymatic, 43(1-4), 29-32. https://doi.org/10.1016/j.molcatb.2006.03.005

West, A. H., Posarac, D., \& Ellis, N. (2008). Assessment of four biodiesel production processes using HYSYS. Plant. Bioresource Technology, 99. https://doi.org/10.1016/j.biortech.2007.11.046

Wong, K. Y., Jo-Han, N., Chong, C. T., Lam, S. S., \& Chong, W. T. (2019). Biodiesel process intensification through catalytic enhancement and emerging reactor designs: A critical review. Renewable and Sustainable Energy Reviews, 116, 109399. https://doi.org/10.1016/j.rser.2019.109399 
Research, Society and Development, v. 10, n. 6, e15210615452, 2021

(CC BY 4.0) | ISSN 2525-3409 | DOI: http://dx.doi.org/10.33448/rsd-v10i6.15452

Yang, L., Nieves-Remacha, M. J., \& Jensen, K. F. (2017). Simulations and analysis of multiphase transport and reaction in segmented flow microreactors. Chemical Engineering Science, 169, 106-116. https://doi.org/10.1016/j.ces.2016.12.003

Yin, X., Duan, X., You, Q., Dai, C., Tan, Z., \& Zhu, X. (2016). Biodiesel production from soybean oil deodorizer distillate using calcined duck egg shell as catalyst. Energy Conversion and Management, 112, 199-207. https://doi.org/10.1016/j.enconman.2016.01.026

Yusuf, N. N. A. N., Kamarudin, S. K., \& Yaakub, Z. (2011). Overview on the current trends in biodiesel production. Energy Conversion and Management, 52(7), 2741-2751. https://doi.org/10.1016/j.enconman.2010.12.004

Zhang, Y., Dube, M., McLean, D., \& Kates, M. (2003a). Biodiesel production from waste cooking oil: 1. Process Design and Technological Assessment. Bioresource Technology, 89(1), 1-16. https://doi.org/10.1016/S0960-8524(03)00040-3

Zhang, Y., Dube, M. A., McLean, D. D., \& Kates, M. (2003b). Biodiesel production from waste cooking oil: 2. Economic Assessment and Sensitivity Analysis. Bioresource Technology, 90(3), 229-240. https://doi.org/10.1016/S0960-8524(03)00150-0 